\title{
10
}

\section{STRATEGIC ADVICE TO THE PUBLIC SERVIGE FACING AUSTERITY}

\author{
Paul McClintock \\ New South Wales Public Service \\ Commission Advisory Board
}

This book is about doing things with less or improving productivity. In business this is linked with competitive advantage, given the role of outputs in the equation. Business has a long history of reducing costs and driving and measuring productivity, and most would agree that it is well ahead of the public sector in this task. This is not surprising, as measuring productivity in the public sector is difficult - the inputs are often reasonably easy, but the outputs and outcomes are not. For some time, productivity in government has been seen more as a reaction to 'efficiency dividends' than as a real analysis of the value of what is produced for what cost.

I welcome the broader focus that is apparent in this book's theme and structure, set out particularly in John Wanna's introductory background chapter. Yet I still feel there is a real danger that we leap into the details of service deliveryimportant as they are - and skip over the broader issue of the value of the output we are measuring. To use a business analogy, we would be surprised if the productivity of a car plant were measured purely by how long the workforce took to screw a bolt on a car, as we all know that the greater productivity benefits are likely to come from designing a car with fewer bolts. Equally in the public sector, a focus on how to deliver more of the same with lower costs 
may miss the greater question of whether we are producing the right outcomes. The best example of this mismatch is the shuddering reaction of business when the government tells us a measure of its success is the number of pieces of legislation it has managed to pass!

Difficulty in measurement should not prevent a broad view of the factors to be considered when looking at public sector productivity. I consider it vital to see the sector as part of the whole national economy, not just because of its size but also for its impact on the rest of us. If there are opportunities from austerity (as suggested by my former COAG Reform Council (CRC) colleague Doug McTaggart in Chapter 2 of this volume) they must include a rethink of what the public sector value-add really is, and is it delivering it at the best possible price for the community?

Let me expand that question by looking at the regulatory burden impacting on the costs of major infrastructure works in Australia, both public and private. This topic has been analysed at length, with the suggestion that delays alone caused by government in many projects add millions to the cost of those works. Every dollar added unnecessarily to spending reduces Australia's national productivity and its international competitiveness.

Every politician and commentator in the country says this is the main game, so one might think that there would be intense scrutiny of whether such costs were justified, or whether the national goals sought, such as proper environmental protection, could be achieved for less. This wider impact on productivity is likely to be far greater than the question of excessive costs within the public sector itself, yet the two are rarely added together to try to assess whether the gains sought are worth the national cost. I very much hope that this book will help us see the larger picture as being the real mountain worth climbing.

Lifting the productivity of policy work or administrative work is particularly challenging. I once attended a lecture presented by the notable Canadian Professor Roger Martin of Integrated Thinking and Design Thinking fame. His talk was on white-collar productivity growth, which he argued from his US studies was around 0 per cent. He went on to state that productivity elsewhere, such as in the factory, remained at its historical average of about 4 per cent, so in terms of the national economy the white-collar workers were seen as the problem. Yet, it seemed to me that the challenge he was throwing out to private business to drive productivity in what he called the 'decision factory' applied even more so to the public service, where white-collar work is disproportionately located. So the challenge here is not one only for the private sector but for the public sector too, and perhaps the sectors have more to learn from each other than they perceive. Interestingly, Professor Martin's thesis for greater white-collar productivity in the private sector involved dramatic 
workplace flexibility, which is a huge challenge for the current way we appoint public sector officials and give them considerable ownership of the static job position they have won through a competitive process.

Let me propose five pieces of strategic advice for public servants and the public service in general.

\section{Be positive-austerity is an opportunity}

First, try to look happy with austerity; it is your chance to get rid of boring jobs you only did because the old minister was paranoid about something happening on his or her watch - or perhaps anything happening at all. Your success is not linked to the people in the department doing menial tasks, like auditors in the old days checking the travel dockets. Spend some time developing really good ideas on what could and should be axed, and take your minister firmly to the issue of function before you get caught up with efficiency.

I tried this idea on a senior officer in the Defence Materiel Organisation, which most readers will know is a large part of our Defence establishment. I suggested that the organisation could not only shed the usual 5 per cent, but could be half as big and much more fun to work in. It would need a different approach to contracting, more discipline in what was bought, and an acceptance by allincluding the Auditor-General and the Senate Estimates committees - that while leaving some discretion does sometimes lead to mistakes, the cost of second guessing everything that is done may not be worth the price.

\section{They are not 'your dollars'}

Second, and this is very relevant to the operation of the Australian federation, give up the concept of a 'Commonwealth' or 'state' dollar - as if the jurisdiction owns these resources. This applies more to the Commonwealth, as they have more dollars to dispense. Efficiency dictates that the Commonwealth is the logical national tax collector, but the Constitution assumes the states deliver most of the services. If we continue to live with this level of vertical fiscal imbalance, and jurisdictions still cling to the concept of 'their dollars', then we will condemn the system to significant overlap between jurisdictions and the consequential waste that goes with it.

I was impressed with at least the theoretical insight of the UK Public Accounts Committee (PAC), which grappled with this dilemma when the Cameron government was elected and was committed to devolve responsibility away 
from Whitehall and into local communities. The PAC is the House of Commons watchdog, with centuries of lively history behind it, and they had come to the view that they would not stop the oversight of a pound unless and until it was handed over to another body with real political accountability for its final destination. They were struggling, as the money was being spent by local authorities that were not seen to have political structures strong enough to ensure real accountability. What joy, I thought, that we have a federation with a national government created by the states, where that level of accountability is clear and well established.

During my six years at the CRC I am not sure I met many politicians or officers who shared this joy and this insight, but it is the essential prerequisite for a productive federation. The perennial round of arguments over school funding is a good example. More money from the federal government always warms the hearts of state politicians and their bureaucrats, but the difficulty in providing such largesse was created by other levels of argument about the appropriate level of Commonwealth involvement in school education. I hope that this debate was conducted thoughtfully in private, concentrating on the many benefits that Commonwealth involvement would bring to the quality of our children's education nationally. In public, however, we rarely got past the 'Commonwealth dollar' point, and most of us watching on got no sense of the value-add of the Commonwealth's arrival - apart from their money. Given that it is difficult to think of an area more in the heartland of state government than school education, it is understandable that the benefits of federal wisdom did not seem self-evident.

\section{Convince the Australian public about long-term sustainability}

Third, try arguing that long-term sustainability can be sold to the Australian public as a worthwhile goal. I know this goes against all the accepted wisdom that expediency triumphs, but perhaps politicians have not tried hard enough. Certainly austerity is a great companion for this view. A pertinent example here is 'generational health reform', and before anyone thinks that we had done that already under the Rudd-Gillard governments, let me tell you we did not get far. We were offered generational change, but instead of asking the difficult question of how to identify and implement a long-term sustainable health system, the reform went straight to telling the states how to fix their public hospitals. The old joke that you wouldn't start from here is apt, as it is hard to conceive a worse place to begin. The Bennett Commission inquiry had given some leads to the question, suggesting that the 20 -year development and roll-out 
of the health system in the Netherlands was the best attempt at new thinking on how to build long-term sustainability into our system - an option for Australia called 'Medicare Select' by the Commission. That recommendation was largely ignored, and yet I felt it was the most important insight in the entire report.

\section{Distinguishing our jurisdictions: We can tell the difference between state and federal responsibilities}

Fourth, we must keep challenging the view that the Australian public is incapable of distinguishing between the roles of different governments. This is a new view largely but not solely held in Canberra, and fed by the growing confusion about the roles of the different levels of government. But it is wrong to accuse the public of driving this confusion - they managed for a century to understand that if hospitals, police, schools and urban infrastructure (including public transport) were inadequate, you blamed the state government. Equally, when issues of the economy, national defence or immigration arose, you looked to the Commonwealth. Now, with a tendency to create blurred accountabilities, we end up in situations where no one is really accountable, or prepared to accept accountability. But this does not need to be the case.

As the head of the CRC, I put it to the prime minister of the day that the Commonwealth government could not give adequate political accountability for an individual hospital, but a state minister could - and did. Accepting that the Commonwealth was by now the dominant funder (and recognising that that was an important development) was bound to move responsibility to the Commonwealth. But, I argued, the responsible Commonwealth minister (whether the Treasurer or the Health minister) could not deliver real accountability for delivery and day-to-day operations. There seemed little acceptance of that view in Canberra. I also could not work out why a Commonwealth minister wanted to have responsibility for each public hospital, given the difficulties inherent in that task.

\section{Attempt tasks that are 'too hard'}

Fifth and finally, I would urge our public officials to push the boundaries on issues that they know are right but which common wisdom suggests are too hard. Austerity affords us a window where conventional wisdom can be challenged. I am conscious that many officials work closely with the political executive, and therefore are constrained in what they can argue for in public, but I wonder 
whether the boundaries are really being pushed in the comparative secrecy of government offices and away from the public arena because we have lowered our expectations of what can be attempted.

In my own personal journey over the past few years I have entered the public arena on four 'too hard' issues: federalism (on behalf of the CRC); medical insurance regulation (on behalf of Medibank); proper process in the Australian Human Rights Commission; and a level playing field for GST tax on imports (both on behalf of Myer). In each case, cautious or wise advisors could have said I was wasting my time or I was taking on vested interests best left alone, but I felt strongly on all four and I thought my arguments should be made with conviction and in public. I was satisfied with the hearing I got in all cases, and although none of them seem as yet to be fully completed I did feel my decision to enter the debate at least enhanced the quality of the discussion. I hope it also improves the final result in each of them.

In my experience, there is nothing more dispiriting than being told by a national leader, politician or official that the points you are making about where Australia could go are both accepted and important, but too hard. This defeatism needs to be fiercely opposed.

Not so long ago I delivered the Sir Roland Wilson Lecture at The Australian National University, and in it I argued the logic for a review of how our federal system is working. In particular, I argued that a change of culture was needed, as I had consistently since I took up the CRC job six years earlier:

Do the players really understand each other? Have they got to know each other and understand their respective talents, experiences and perspectives? Do they train together, think strategically together, spend time together beyond what is required to do today's tasks? Or is the great collective effort of leading Australiawhich is shared by all our governments - a hostage to the electoral cycle, marked with cynicism, suspicion and lack of respect? (McClintock 2012).

This is a challenge for us all. The federation needs a great deal more investment, and our think tanks and executive development agencies such as the Australia and New Zealand School of Government (ANZSOG) should be a key part of the solution. I then went on to argue that both major political parties should have an approach to the federation to put to the electorate, so that they can 'read any policies that are impacted by the federal system - including health and education, disability and indigenous disadvantage, housing and trainingin light of that federalism policy. If they are not in harmony, put a serious discount on the lot!' (McClintock 2012). 
After that speech I was pleased to see the Coalition's commitment, given in the Leader's Budget Reply speech of 2013, to conduct a review of the federal system with the states, leading to a White Paper within a couple of years of their election to government (Abbott 2013). This exercise is perhaps a real opportunity to give these issues the attention they crave, and a new philosophical base will give us real guidance on how the whole system should run. I also welcome the growing prominence given to this issue by my business colleagues, particularly by the Business Council of Australia. So maybe we will have another chance at major reform and produce tangible benefits and lift national productivity - I know many are waiting for it.

\section{Conclusion}

To sum up, I urge all those who seek to influence government to try out my principles:

1. Embrace austerity and be creative on function.

2. Give up the ownership of a tax dollar - it belongs to the community and not to any government - and let responsibility flow to the party who controls the outcomes.

3. Long-term sustainability must be championed in the community and its support will be secured.

4. The community is capable of holding different levels of government accountable if they stay out of each other's business.

5. Challenge the 'too hard' assumptions - get a bit ambitious, or least get us free from mediocre aspirations that will leave us in the austerity zone for a long time.

This may sound simple, although I do accept that it is not. But let me end with a view of what is at stake. Australia has a wealth-generating sector that has been successful enough to fund generously a government sector empowered to control the use of that wealth, and to encourage its further generation. I have observed the Australian political scene closely for nearly half of the life of the federation - I started as the young son of a senior Canberra official-and the confidence and respect between the public and private sectors is profoundly low. It affects not only the political class, but also the public service. This gulf will do great damage to the nation if it is not addressed, and we all have a part to play. 


\section{References}

Abbott, Tony. 2013. 'Budget reply speech.' Parliament House, Canberra, 17 May. Online: www.liberal.org.au/latest-news/2013/05/16/tony-abbott-budget-replyparliament-house-canberra (accessed 14 April 2014).

McClintock, Paul. 2012. 'Harnessing federalism - the missing key to successful reform.' Sir Roland Wilson Foundation Lecture at the Crawford School of Public Policy, The Australian National University, Canberra, 19 November. Online: $\quad$ www.coagreformcouncil.gov.au/media/speeches/2012-11-19 (accessed 14 April 2014). 
This text is taken from Managing Under Austerity, Delivering Under Pressure, edited by John Wanna, Hsu-Ann Lee and Sophie Yates, published 2015 by ANU Press, The Australian National University, Canberra, Australia. 